\title{
СТАНОВЛЕННЯ ОСОБИСТОСТІ
}

\author{
https://doi.org/10.32820/2074-8922-2018-61-129-136 \\ УДК 37.091.212.3
}

\section{СУЧАСНІ ПИТАННЯ ОБДАРОВАНОСТІ: ПРИРОДА, СТРУКТУРА ТА РОЗВИТОК СКарпова Л.Г. Харківський національний університет ім. В.Н. Каразіна}

Інформація про автора:

Карпова Лариса Георгіївна: ORCID: 0000-0002-3481-8324; deductionmax@gmail.com; кандидат педагогічних наук, доцент, викладач кафедри прикладної психології, Харківський національний університет ім. В.Н. Каразіна, площа Свободи, 4, м. Харків, 61022, Україна.

Обдарованість складається 3 індивідуальної потенційної своєрідності задатків, сприятливого соціального середовища та особистісного потенціалу, завдяки яким можна досягти значних успіхів у певній галузі діяльності. Проблема обдарованості містить у собі цілий ряд аспектів: психологопедагогічний, методичний, організаційний, філософський, соціальний тощо. Самостійною та багатоплановою проблемою є розгляд творчого потенціалу особистості, адже лише здійснення комплексного підходу уможливлює врахування всіх можливих тенденцій та явищ.

У статті зазначається, що в сучасній психолого-педагогічній думці не існує універсального, визнаного і прийнятого всіма дослідниками визначення поняття «обдарованість». Обдарованість в ракурсі психологічних енциклопедичних даних визначають як більш загальну характеристику сфери здібностей, також вказуючи на комплексний підхід до вивчення поняття (психофізіологічний, психологічний та соціально-психологічний).

Звертається увага на історію дослідження природи обдарованості, iї витоків та засад, при цьому робиться акцент та аналіз важливого питання щодо сучасних наукових уявлень про обдарованість, зміст, структуру та розвиток.

Ключові слова: обдарованість, потенціал особистості, задатки, талант, інтелект, креативність, структура обдарованості, ядро обдарованості, чинники обдарованості.

Kapnoва Л. $\boldsymbol{\Gamma}$. «Современные вопросы одаренности: природа, структура и развитие»

Статья посвящена одной из важных проблем - теоретико-методологическому анализу современных психолого-педагогических взглядов на одаренность.

Одаренность состоит из индивидуальной потенциальной своеобразия задатков, благоприятной социальной среды и личностного потенциала, благодаря которым возможно достичь значительных успехов в определенной области деятельности. Проблема одаренности содержит в себе целый ряд аспектов: психолого-педагогический, методический, организационный, философский, социальный и т.д. Самостоятельной и многоплановой проблемой является рассмотрение творческого потенциала личности, ведь осуществление комплексного подхода позволяет учесть все возможных тенденции и явления.

В статье отмечается, что в современной психолого-педагогической мысли не существует универсального, признанного и принятого всеми исследователями определения понятия «одаренность». Одаренность в ракурсе психологических энциклопедических данных определяют как более общую характеристику сферы способностей, также указывая на комплексный подход к изучению понятия (психофизиологический, психологический и социально-психологический).

Обращается внимание на исторический опыт изучения природы одаренности, ее истоков и основ, при этом делается акцент и анализ важного вопроса о современных научных представлениях об одаренности, содержании, структуре и развитии.

Ключевые слова: одаренность, потенциал личности, задатки, талант, интеллект, креативность, структура одаренности, ядро одаренности, факторы одаренности.

L. Karpova "Modern issues of giftedness: nature, structure and development"

The article is devoted to one of the important problems, which is a theoretical and methodological analysis of modern psychological and pedagogical views on giftedness.

Giftedness consists of an individual original potential set of natural inclinations, a favorable social environment and personal potential, which make it possible to achieve significant success in a certain area of activity. The issue of giftedness contains a number of aspects, namely psychological, pedagogical, methodological, organizational, philosophical, social, etc. An independent multidimensional problem is the 


\section{СТАНОВЛЕННЯ ОСОБИСТОСТІ}

consideration of the creative potential of the individual, because it becomes expedient, while implementing an integrated approach, to take into account all possible trends and phenomena.

The article highlights that in modern psychological and pedagogical thought there is no universal, recognized and accepted by all researchers definition of the concept of «giftedness». Through the prism of psychological encyclopedic data, giftedness is defined as a more general description of the scope of abilities, also pointing to an integrated approach to the study of the concept (psycho-physiological, psychological and socio-psychological).

Attention is paid to the historical experience of studying the nature of giftedness, its origins and foundations, while emphasizing and analyzing an important issue of how modern science perceives the phenomenon of giftedness, its content, structure and development.

Keywords: giftedness, personal potential, inclinations, talent, intelligence, creativity, structure of giftedness, core of giftedness, factors of giftedness.

Постановка проблеми. Дослідження проблеми обдарованості має тривалу історію у вітчизняній та зарубіжній науці. Творчо обдарована людина $€$ найбільшою цінністю будь-якого суспільства. Проблема обдарованості містить у собі цілий ряд аспектів: психолого-педагогічний, методичний, організаційний, філософський, соціальний та інші.

Виступаючи

в статусі міждисциплінарного предмету дослідження, сутність природи людини, iii багатогранна індивідуальність базуються на проблемах обдарованості, геніальності, таланту, що всебічно досліджуються. Самостійною та багатоплановою проблемою $\epsilon$ розгляд творчого потенціалу особистості, адже саме здійснення комплексного підходу уможливлює врахування всіх можливих тенденцій та явищ.

Аналіз останніх досліджень i публікацій. $\mathrm{y}$ психолого-педагогічній літературі знайшли відображення такі аспекти досліджуваної тематики: проблеми здібностей та обдарованості в роботах вітчизняних (О. Антонова, Г. Бурменська, I. Біла, Н. Ваганова, Ю. Гільбух, М. Гнатко, С. Гончаренко, О. Кульчицька, М. Лейтес, А. Марушкевич, В. Моляко, О. Музика, А. Петровський, С. Рубінштейн, В. Слуцький, Б. Теплов, В. Тесленко, Л. Чорна, Т. Яншина) та зарубіжних науковців (Б. Блум, Г. Гарднер, Дж. Гілфорд, Ф. Монкс, Дж. Рензул, Р. Стенберг, А. Танненбаум, Л. Терман, П. Торранс, К. Хеллер); питання психологічних чинників, що більшою чи меншою мірою притаманні обдарованим (А. Адда, Е. Картру, К. Роджерс, Л. Холлінгуорт, А. Віннер).

В. Маляко вказує на те, що творчий потенціал особистості розглядають всебічно, навіть із суперечностями та нечіткими характеристиками [2].

Так, у дослідженнях існують різнопланові погляди на визначення феномену обдарованості, зокрема зазначають, що коефіцієнт інтелекту не завжди обумовлює вірогідні високі здібності, існує поняття індивідуально-психологічних особливостей навіть обдарованих людей тощо. Зарубіжні автори виокремлюють надобдарованість та геніальність у рамках своїх наукових доробок. Тому $\epsilon$ необхідним зробити аналіз питань обдарованості, враховуючи сучасні психологопедагогічні концепції.

Постановка завдання. Метою нашої статті $\epsilon$ теоретико-методологічний аналіз сучасних психолого-педагогічних поглядів на обдарованість.

Виклад основного матеріалу. В сучасній психолого-педагогічній думці не існує універсального, визнаного і прийнятого всіма дослідниками визначення поняття «обдарованість». При цьому уявлення про обдарованість, ii природу та сутність формувалися в суспільній свідомості тисячоліттями. Зокрема мислителі давнього світу були зосереджені на тому, що кожна людина має здібності до певного виду діяльності, зумовлені природними задатками, подальший розвиток яких стає можливим лише за умови відповідних виховних впливів оточуючого середовища. Така тенденція $\epsilon$ актуальною i в наш час. Зокрема, О. Антоновою було сформульовано робоче визначення поняття обдарованості, що складається 3 індивідуальної потенційної своєрідності задатків (внутрішні передумови), сприятливого соціального середовища (зовнішні умови) та особистісного потенціалу (позитивна «Я»-концепція, наявність відповідних вольових якостей, спрямованості, наполегливості тощо), завдяки яким можливо досягти значних успіхів у певній галузі діяльності [1].

У Середньовіччі всі відповіді на свої запитання люди шукали тільки в релігійному вимірі, не заглиблюючись у людську природу, в особливості людського мислення, психіки, 


\section{СТАНОВЛЕННЯ ОСОБИСТОСТІ}

проблеми їх розвитку. Вже арабські вчені звертаються до психолого-педагогічних проблем дитинства та наголошують на необхідності різнобічного розвитку особистості дитини в школі. В епоху Відродження проблематика обдарованості хвилювала багатьох європейських учених, було окреслено ряд теоретичних положень, що були визначені як передумови до формування в майбутньому психології обдарованості, зокрема психології творчої обдарованості.

Провідні мислителі Просвітництва та Нового часу визнають існування нерівності між людьми на основі їх здібностей, що надала природа. Згодом висувається гіпотеза про зв'язок вираженості психічної властивості 3 імовірністю іiі прояву, що $€$ теоретичними засадами психометрики. $\mathrm{XX}$ століття відрізняється значним науковим інтересом до природи обдарованості , пошуком методів вимірювання природних здібностей особистості та рівня розвитку іiі інтелекту, виникненням спеціальних систем стосовно виховання обдарованих дітей тощо [1].

Отже, проаналізувавши історичний досвід дослідження природи обдарованості, іiі витоків та засад, вважаємо, що важливим $€$ питання про сучасні наукові уявлення про неї, зміст, структуру та розвиток.

В. Маляко зазначає, що в розумінні поняття обдарованості 3 урахуванням психологічного фактору необхідно здійснення комплексного підходу [2]. Т. Яншина підкреслює той факт, що в сучасному науковому просторі не існує єдиного підходу до визначення поняття «обдарованість», що це ускладняється ще й тим, що не існує поняття для визначення дітей, які відрізняються від однолітків високим рівнем розвитку інтелекту та особистісними якостями. Дослідниця зазначає, що можна погодитись із визначенням зарубіжних учених щодо введення ними поняття «надобдоровані» щодо характеристики таких дітей [11].

Вивчаючи поняття обдарованість в ракурсі психологічних енциклопедичних даних, характеризують ii як більш загальну характеристику сфери здібностей, також вказуючи на комплексний підхід до вивчення поняття (психофізіологічний, психологічний та соціально-психологічний). У психологічному тлумачному словнику поняття «обдарованість» має такі значення: якісно своєрідне сполучення здібностей, загальні здібності або їх характеристики, розумовий потенціал або інтелект, цілісна індивідуальна характеристика пізнавальних можливостей та здібностей, комплекс задатків, природних даних, характеристика ступеня та своєрідності природних передумов здібностей, талановитість, наявність внутрішніх умов для видатних досягнень у діяльності $[6,10]$. Так, творчість $є$ універсальною характеристикою активності людини, вона виявляється в будьяких іiі видах та етапах [9].

Визначення обдарованості в теоретичному та практичному планах в деяких дослідженнях базуються на такому аспекті, як коефіцієнт інтелекту. По-перше, приділяючи увагу тільки інтелектуальним здібностям, визначають обдарованість у рамках концепції генетично обумовленого інтелекту (Ф. Гальтон) та концепції біологічно детермінованого розвитку в онтогенезі (А. Біне). По-друге, дослідники схиляються до думки, що існує багато різних взаємопов'язаних детермінуючих інтелектфеноменів, що визначають обдарованість [11].

Тривалий час обдарованість ототожнювалася 3 виключно високим рівнем розвитку інтелекту. Тому становлення інтегративного підходу, що затвердив поняття «загальна обдарованість», призвело до зведення його до поняття «інтелектуальна обдарованість». Так, із розвитком досліджень проблеми обдарованості базування тільки на інтелект особистості почало суперечити реальним отримуваним результатам. Тривале лонгітюдне дослідження Л. Термана дозволило зробити висновок, що для досягнення видатних результатів у різних сферах діяльності часто потрібен не високий інтелект, a якась інша складна якісна своєрідність психіки особистості - здатність генерувати нові, оригінальні ідеї, знаходити нетрадиційні способи розв'язування проблемних задач. Ця якість була визначена як «креативність» [1].

Отже, у моделях обдарованості розглядали тільки інтелектуальні та творчі фактори в першу чергу, потім дійшли висновку, що необхідно приділяти увагу й особистісним якостям. В сучасному розумінні постає проблема створення системи виявлення, навчання та розвитку обдарованих дітей.

Для аналізу вищезазначеного розроблені та запропоновані моделі обдарованості, а саме: моделі, що базуються на здібностях (Г. Гарднер); моделі, які базуються на результатах діяльності (Дж. Рензулл); когнітивні моделі (Р. Стенберг, К. Хеллер, Р. Ганьє, Л. Перес); соціокультурні моделі (А. Танненбаум). Серед сучасних концепцій обдарованості найбільш визнаною є модель, 


\section{СТАНОВЛЕННЯ ОСОБИСТОСТІ}

яка складається 3 трьох компонентів: здібностей (загальних та спеціальних), що сягають рівня розвитку, вищого за середній; креативності особистості; мотивації (спрямованості, наполегливості) особистості до певного виду діяльності $[1,11]$.

За Г. Гарднером, у рамках моделей обдарованості, що базуються на здібностях, компетенцією в деяких галузях, що проявляється у взаємодії особистості 3 навколишнім світом, є здібності. Дж. Рензулл (моделі, які базуються на результатах діяльності) вважає, що здібності можуть бути загальними та специфічними. Загальна здібність є здатністю обробляти та утримувати інформацію, інтегруючи набутий досвід у нові обставини. Специфічна здібність відображає спроможність набувати нові знання i компетенції в різних галузях; мотивації $[1,2]$.

Когнітивні моделі базуються на когнітивних процесах, використовуючи складні завдання, їх перевага в тому, що $є$ можливість ідентифікувати когнітивні процеси, стратегії та структури, завдяки яким досягаються високі результати. Аналізуючи когнітивні моделі, можна зрозуміти механізми інтелектуальної діяльності та складові, що відрізняють обдарованих людей від тих, які не $\epsilon$ ними, а також визначити їх кількісно та якісно, що дає змогу в розробленні методів навчання та розвитку обдарованості.

Виходячи 3 когнітивної моделі Р. Стенберга, такі критерії, як перевага, надзвичайність, продуктивність, демонстративність та цінність, $є$ критеріями обдарованої особистості. Максимально високі результати успішності у виконанні запропонованого тесту, у порівнянні з іншими, визначаються як переваги. Надзвичайність це високий рівень виконання діяльності, продуктивність - високі показники виконання тестових завдань як доказ того, що особистість реально демонструє високі результати в окремій предметній галузі. При демонстративності підтверджуються високі результати виконання тестових завдань в інших валідних вимірюваннях, альтернативних ситуаціях. Важливість психологічної якості в конкретному соціо-культурному середовищі втілюється в цінностях [1].

Модель К.Хеллера, що розроблена в рамках когнітивних моделей обдарованості, включає фактори обдарованості, фактори середовища, досягнення та некогнитивні особистісні особливості. Дослідження К. Хеллера є тривалим, його метою є виявлення та спеціальне навчання обдарованих дітей, воно побудовано на базі розробленої автором багатофакторної моделі («Мюнхенська модель обдарованості»). Фактори обдарованості визначаються ним як інтелектуальні здібності, креативність, соціальна компетентність тощо. Фактори середовища - мікроклімат у сім'ї, мікроклімат у класі та ін. Досягнення - спорт, мови, природничі науки та ін. Некогнітивні особистісні особливості вбачаються в подоланні стресу, мотивації досягнення, стратегіях роботи і навчання тощо [4].

У моделі Ф. Ганьє були виділені здібності інтелектуальні, креативні, соціальноафективні, сенсомоторні та інші. Також різні галузі застосування таланту (мистецтво, спорт, природничі науки i техніка, виховання, охорона здоров'я тощо) мали місце в рамках поглядів Ф. Ганьє. Оформлення таланту відбувається під впливом надійного каталізатору. Л. Перес, як представник когнітивних моделей обдарованості, визначає три основні аспекти. По-перше, вірогідні, тобто здібності, що можливо будуть розвиватися протягом життя. По-друге, потенційні, а саме - здібності, розвиток яких залежить від того, наскільки певні здібності необхідні суспільству, родинному та соціальному оточенню, соціальноекономічному стану; по-третє, велика увага приділяється особистісним якостям, таким, як самопізнання та самоконтроль. Згодом ця модель («зрощування»), що виражає більше комбінацію якісних, ніж кількісних критеріїв, набула такого вигляду, що складається 3 трьох компонентів: інтелект, потенційні здібності та мотивація. Як загальна якість, є необхідною, але недостатньою умовою розвитку високих здібностей; потенційні здібності, що стають детермінантами у досягненні вищого розвитку обдарованості; мотивація та різні особистісні якості, що $є$ умовою високого розвитку обдарованості.

П'ятифакторна модель А. Танненбаума (соціокультурні моделі) визначає роль культурних факторів та середовища у визначенні обдарованості та складається 3 таких компонентів: певний вид загадкової інтелектуальної енергії, що необхідний для розуміння та розв'язання проблем; високого рівня спеціальних здібностей у конкретній галузі; неінтелектуальних факторів (вольових, мотиваційних, особистісних тощо); впливу стимулюючого оточення (культурного середовища, родини, друзів тощо); спеціальних характеристик неінтелектуального характеру (мотивація, наполегливість, 
впевненість у собі тощо); середовища та випадкових факторів [11].

У середині XX ст. завдяки дослідженням американського психолога Дж. Гілфорда 3'являється сучасна психологія творчої обдарованості (психологія креативності). Дж. Гілфорд виділив два базові типи мислення: дивергентний i конвергентний. Дивергентний тип - продукування багатьох рішень проблемної ситуації на основі однозначних вихідних даних. Дж. Гілфорд вважав, що саме дивергентний тип є «ядром» творчої обдарованості, креативності. Виділив чотири основні параметри творчої обдарованості: оригінальність, семантичну гнучкість, семантичну спонтанну гнучкість, образну адаптивну гнучкість. Оригінальність спроможність продукувати віддалені асоціації, незвичні відповіді. Семантична гнучкість здатність виділяти функцію об'єкта та пропонувати його нове застосування. Семантична спонтанна гнучкість спроможність продукувати різноманітні ідеї в нерегламентованій ситуації. Образна адаптивна гнучкість - спроможність змінювати форму відображуваного стимулу таким чином, щоб виявити в ньому нові ознаки й можливості для використання. На основі відокремлених теоретичних напрацювань Дж. Гілфорд із співробітниками розробив тестову програму дослідження творчої обдарованості. Згодом американський психолог, учень і послідовник Дж. Гілфорда П. Торранс розробив пакет психодіагностичних тестових методик виявлення творчої обдарованості $[6,7]$.

Отже, в рамках сучасних моделей визначають такі поняття при описі обдарованості: системна якість психіки, що розвивається протягом усього життя, визначає можливості досягнень людиною виключно високих результатів в одній чи декількох видах діяльності порівняно 3 іншими людьми; здатність до видатних досягнень у будь-якій соціально значущій сфері людської діяльності, а не тільки в академічній галузі; ступінь вираження таланту; одне 3 ключових суб'єктних детермінант активності людини, що забезпечує високий рівень цієї активності; уявлення про спадкові передумови, про рівень розумового розвитку, що характеризує кожну людину; досягнення і можливість досягнень (актуальні та потенційні) [3].

У сучасних моделях структура розвиненої обдарованості включає три основних підструктури: 1) високу пізнавальну активність, що спирається на високочутливу сенсорику (увага, сприймання, пам'ять) та дивергентне мислення (оригінальність, критичність, здатність до узагальнення, прогнозування); 2) творчу інтерпретацію пізнавального досвіду (вміння порівнювати, зіставляти, аналізувати, бачити нове, реконструювати раніше створене, оригінальний підхід до рішення проблем, варіативність у розв'язанні задач); 3) емоційну захопленість діяльністю (інтерес, висока харизма, впевненість у досягненні успіху, «відновлення» в разі неуспіху) $[4,5]$.

О. Антоновою запропоновано робочу модель обдарованості, в яку входять ядро обдарованості та чинники, що впливають на рівень реалізації основних компонентів ядра обдарованості. Ядро обдарованості складається зі здібностей, креативності та спрямованості особистості до певного виду діяльності. Сукупність індивідуальнопсихологічних особливостей, що $є$ умовою успішного, високоякісного виконання людиною певної діяльності i зумовлюють різницю в динаміці оволодіння необхідними для неї знаннями, вміннями та навичками, визначають як здібності. Здатність до творчого пошуку, нестандартного розв' язування задач $є$ креативністю. Спрямованість особистості до певного виду діяльності визначається в бажанні працювати саме в цій сфері, отримувати задоволення від діяльності, постійно повертатися до неї. Чинники робочої моделі обдарованості складаються 3 таких компонентів: спадкові дані, середовище, виховні впливи, досвід виконання діяльності, особливості емоційно-вольової сфери, наявність системи цінностей та випадковість [1].

Отже, в рамках чинників сучасної робочої моделі обдарованості, що впливають на іï рівень реалізації, розглянемо розробки щодо розвитку обдарованості. В. Тесленко запропонована організація процесу становлення та формування обдарованої особистості в рамках регіональної педагогічної системи, що включає в себе комплекс психолого-педагогічних, організаційних та інших напрямків роботи 3 обдарованими дітьми, при цьому відзначається значна роль у наданні процесу розвитку обдарованості інноваційного характеру. В основу розробленої ідеї покладено індивідуальнодиференційований підхід, реалізація якого передбачає аналіз та визначення для кожної обдарованої дитини таких властивостей, як: темп оволодіння змістом освіти; $30 \mathrm{H}$ найближчого розвитку; особистісного 


\section{СТАНОВЛЕННЯ ОСОБИСТОСТІ}

розвитку; сфер індивідуальності (інтелектуальної, мотиваційної, предметнопрактичної; екзистенційної). У цьому процесі має важливе значення діяльність професійних педагогів, управлінських і методичних структур $[7,8]$.

Визначають, що для активізації творчого сприймання дітей важливо збагачувати різноманітними враженнями, створювати предметне середовище, сприяти розвитку спостережливості, вмінню бачити характерні особливості предмета, запам'ятовувати їх i відтворювати в процесі роботи, тобто необхідно враховувати сенситивний період становлення i стимулювання сенсорної, пізнавальної діяльності, перцептивної активності. У нагоді може також стати поняття метапізнання, що є системою знань людини про особливості власної пізнавальної сфери та засоби тї контролю, тобто пізнання про пізнання в процесі розвитку обдарованості.

Н. Шумакова вважає основою навчання та розвитку обдарованих дітей міждисциплінарним підходом. Адже в освіті обдарованих дітей не можна обмежувати тільки розвитком інтелекту, процес навчання та виховання повинен торкатися особистості дитини. Дослідники говорять про необхідність визначеної структури освітнього середовища та його спеціального проектування, відмічається поєднання динаміки розвитку особистості та розвитку культури, як «екологічної ніші» творчої особистості [11].

Учені звертають увагу на невідповідність норми рівня інтелектуального розвитку дітей в окремих регіонах країни та розвитку їхніх емоцій згідно 3 віком. Таким дітям важко знайти однодумців, пояснити оточуючим нестандартність своїх учинків. Обдаровані особистості в усьому дотримуються порядку, системи, що складає враження про них як владолюбних, зверхніх, негнучких, тих, які діють «цілеспрямовано, наполегливо, часто нехтують своїми обов'язками, порушують графіки роботи інших людей». Вони розраховують лише на свої можливості, в усьому надають перевагу самостійності, «їм притаманне сильне відчуття гумору, що вони використовують для привернення уваги оточуючих» [3].

Сучасні дослідження розвитку обдарованості визначають, що алгоритму творчості не існуе, але можна навчитися використовувати свій творчий потенціал, можна навчитися думати, шукати і знаходити кращі рішення. Суттєвим фактором, що впливає на підвищення рівня успішності молоді, $\epsilon$ уявлення про успішну людину. Ідеальний образ успішної людини $\epsilon$ найважливішим детермінантом діяльності i розвитку особистості. Саме тому важливим стає досвід та бачення цілеспрямованого формування образу успішної людини. Проблема обдарованості завжди була в полі зору провідних вітчизняних та зарубіжних учених. Водночас Є. Бирук., I. Зарицька, I. Толкунова та ін. підкреслюють значущість не лише виявлення обдарованої молоді та ii залучення в специфічну діяльність або навчання (y відповідних спеціальних закладах), а осмислення засад запобігання та подолання бар'єрів самореалізації [5].

Вивчаючи рефлексію та динаміку розвитку здібностей, О. Музика виходить 3 того, що для розвитку здібностей, особливо творчих, важливим $\epsilon$ процес усвідомлення суб'єктом окремих умінь, дій та операцій, усвідомлення цінності діяльності, що відбувається через оцінку референтних осіб. При цьому не менш важливою є рефлексія людиною власних особистісних якостей, що розвиваються в процесі розвитку здібностей. Рушійними силами розвитку особистості в будь-якому віці є суперечності, що виникають між потребами та можливостями їх задоволення в реальних ситуаціях соціальної взаємодії, як зазначають О. Запорожець, Г. Костюк та інші дослідники [2].

Висновки та перспективи подальших досліджень.

У результаті проведеного теоретикометодологічного аналізу сучасних психологопедагогічних поглядів на обдарованість можемо зробити такі висновки. Не існуе універсального, визнаного і прийнятого всіма дослідниками визначення поняття «обдарованість» у сучасній психологопедагогічній думці.

Мислителі давнього світу були зосереджені на тому, що кожна людина має здібності до певного виду діяльності. У Середньовіччі пошуки будь-якого питання знаходили в релігійному вимірі, арабські вчені зверталися до психолого-педагогічних проблем дитинства та наголошували на необхідності різнобічного розвитку особистості дитини в школі. В епоху Відродження було здійснено ряд теоретичних положень, що були визначені як передумови до формування в майбутньому психології обдарованості, зокрема й психології творчої обдарованості. Провідні мислителі Просвітництва та Нового часу визнають існування нерівності між людьми на основі їх 
здібностей, що надала природа. Сучасні погляди відрізняються значним науковим інтересом до природи обдарованості , пошуком методів вимірювання природних здібностей особистості та рівня розвитку іiі інтелекту, виникненням спеціальних систем стосовно виховання обдарованих дітей тощо

У наведених моделях інтелекту відводиться роль значущого та провідного фактору в прояві обдарованості. В основу цих моделей покладено інтелект із різними факторами у вигляді конвергентних здібностей, креативності, здатності до навчання, навіть чинника вдач або до інтелекта додаються ще й особистісні якості, але мова йде про критерії ідентифікації обдарованої особистості, а проблема психологічних механізмів обдарованості залишається поза увагою.

Розвинена обдарованість має свою структуру як категоріальний компонент i включає три основних підструктури: високу

\section{Список використаних джерел}

1. Антонова О. Є. Обдарованість: досвід історичного та порівняльного аналізу: Монографія / О. Є. Антонова. - Житомир : Житомир. держ. ун-т, 2005. $-456 \mathrm{c}$.

2. Здібності, творчість, обдарованість: теорія, методика, результати досліджень / За ред. В. О. Моляко, О. Л. Музики. - Житомир : Вид-во Рута, 2006. $-320 \mathrm{c}$.

3. Марушкевич А. А. Досвід підтримки та розвитку обдарованої молоді країн Європи в аналітиці сучасних учених / А. А. Марушкевич // Освіта та розвиток обдарованої особистості. - 2014. - № 2. - C. 5-8.

4. Навчання і виховання обдарованої дитини: теорія та практика : зб. наук. праць. Вип. 16. / В. В. Камишин (гол. ред.) [та ін.]. - Київ : Інститут обдарованої дитини, 2016. - 158 c.

5. Організація творчого сприймання на різних вікових рівнях : методичні рекомендації / В. О. Моляко [та ін.] ; за ред. В. О. Моляко. - Київ : Педагогічна думка, 2015. - 57 с.

6. Психологічна енциклопедія: А - Я / О. М. Степанов (авт.-упоряд.). - Київ : Академ-видав, 2006. - 424 с. - (Серія: «Енциклопедія ерудита»).

7. Світові мережеві ресурси підтримки розвитку обдарованості. - Київ : Інститут обдарованої дитини, 2012. - 52 с. - (Серія: «ПРОсвіт»).

8. Тесленк В. Регіональна педагогічна система розвитку обдарованих учнів / В. Тесленко // Психолого-педагогічні проблеми сільської школи. - 2013. - № 45. - С. 138-150.

9. Чорна Л. Г. Шляхи оптимізції становлення рольової ідентичності людини в контексті розвитку iii творчого потенціалу / Л. Г. Чорна // Обдаровані пізнавальну активність, що спирається на високо чутливу сенсорику та дивергентне мислення; творчу інтерпретацію пізнавального досвіду та емоційну захопленість діяльністю. Виявлення дитячої обдарованості, iї розвиток i перехід в обдарованість дорослої людини має величезне значення для сучасного трансформаційного суспільства, що потребує професійні кадри, що здатні досягти високих результатів не тільки в професійній діяльності. Обдарованість дитини носить несвідомий характер, перебуває в потенційному стані, виявляється у різних видах діяльності. Вибір діяльності дитиною частіше за все не має раціональних мотивів, а заснований на ситуативному інтересі до того чи іншого виду діяльності. Обдарованість дорослої людини - цілеспрямована. Доросла людина усвідомлено мотивує себе на певний вид діяльності, що може знайти форму професійної. Цей напрям покладено в основу наших подальших досліджень.

діти - інтелектуальний потенціал держави. - Київ : Ін-т обдарованої дитини НАПН України. - 2013. C. 120-126.

10. Шапар В. Б. Психологічний тлумачний словник / В. Б. Шапар. - Харків : Прапор, 2004. $640 \mathrm{c}$.

11. Яншина Т. А. Обдарованість : Психолого-педагогічний аспект / Т. А. Яншина // Освіта та розвиток обдарованої особистості. - 2013. - № 08-09 (15-16). - С. 116-120.

\section{References}

1. Antonova, OIe 2005, Obdarovanist: dosvid istorychnoho ta porivnialnoho analizu, [Giftedness: the experience of historical and comparative analysis], Zhytomyrskyi derzhavnyi universytet, Zhytomyr.

2. Moliako, VO \& Muzyka, OL (eds.) 2006, Zdibnosti, tvorchist, obdarovanist: teoriia, [Abilities, creativity, giftedness: theory, methodology, research results], metodyka, rezultaty doslidzhen, Vydavnytstvo Ruta, Zhytomyr.

3. Marushkevych, AA 2014, 'Dosvid pidtrymky ta rozvytku obdarovanoi molodi krain Yevropy $\mathrm{v}$ analitytsi suchasnykh uchenykh'[The experience of supporting and developing gifted youth in Europe in the analysis of modern scholars], Osvita ta rozvytok obdarovanoi osobystosti, no. 2, pp. 5-8.

4. Kamyshyn, VV (ed.) 2016, Navchannia $i$ vykhovannia obdarovanoi dytyny: teoriia ta praktyka, [Teaching and upbringing of a gifted child: theory and practice] iss. 16, Instytut obdarovanoi dytyny, Kyiv.

5. Moliako, VO et al. 2015, Orhanizatsiia tvorchoho spryimannia na riznykh vikovykh rivniakh, [Teaching and upbringing of a gifted child: theory and practice] Pedahohichna dumka, Kyiv. 
ISSN 2074-8922 «Проблеми інженерно-педагогічної освіти», 2018, № 61

\section{СТАНОВЛЕННЯ ОСОБИСТОСТІ}

6. Stepanov, OM 2006, Psykholohichna entsyklopediia: $A-Y a$, [ Psychological Encyclopedia: A - Z] Akadem-vydav, Kyiv.

7. Svitovi merezhevi resursy pidtrymky rozvytku obdarovanosti 2012,[ World network resources to support the development of giftedness] Instytut obdarovanoi dytyny, Kyiv.

8. Teslenko, V 2013, 'Rehionalna pedahohichna systema rozvytku obdarovanykh uchniv'[Regional pedagogical system of development of gifted students], Psykholoho-pedahohichni problemy silskoi shkoly, no. 45, pp. $138-150$.

9. Chorna, LH 2013, 'Shliakhy optymiztsii stanovlennia rolovoi identychnosti liudyny v konteksti rozvytku yii tvorchoho potentsialu'[Ways of optimization of the formation of the role identity of a person in the context of the development of his creative potential], Obdarovani dity - intelektualnyi potentsial derzhavy, Instytut obdarovanoi dytyny Natsionalnoi akademii pedahohichnykh nauk Ukrainy, Kyiv , pp. 120-126.

10. Shapar, VB 2004, Psykholohichnyi tlumachnyi slovnyk, [Psychological explanatory dictionary] Prapor, Kharkiv.

11. Yanshyna, TA 2013, 'Obdarovanist : psykholoho-pedahohichnyi aspekt'[Giftedness: Psychological-pedagogical aspect], Osvita ta rozvytok obdarovanoi osobystosti, no. 08-09 (15-16), pp. 116120.

Стаття надійшла до редакиії 25.09.2018p. 